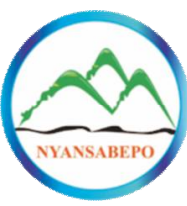

Available online at www.ktu.edu.gh

International Journal of Technology and Management Research 3 (2018)

International Jowmal

of Technology and

Management Research

\title{
Sustainable Knowledge Investment and Retums in Ghana
}

\author{
Eric Fifi Ankamah, Joseph Yao Amoah \\ Camil for SaientificandIndustrial Reserth- Instituteof Industrial Reserch P.O. Box 576, Legn, Ghama \\ Email: fifiankamah@yahoacam
}

\begin{abstract}
This study measured the rate of returns for knowledge asset as Gross D omestic Product (GDP) per capita, (a human progress indicator) rather focuses on production and consumption of scarce tangible assets. Knowledge investment rate of return is beneficial, because, knowledge is a limitless intangible asset, growth enhancing and sustainable, thus, also averting the challenges of Knowledge Economy Index (KEI). Sustainable Knowledge Investment Returns can ensure quality higher education, improvement in scientific research and accelerate attainment or consolidation of achieved Sustainable Development Goals (SD G) in a poor country like Ghana. The Council for Scientific and Industrial Research (CSIR), G hana, data from 2009 to 2015 was used. In 2009, a rate of return of approximately 54\% was obtained through the production function method. The financial method was used to calculate the remaining mean rates of approximately 36\% for 2010 and 2011, negative 18\% for 2012 and 2013 and approximately 59\% for 2014 and 2015. Fluctuation in investment returns were accounted for by investments, incentives and schemes that foster demand for knowledge (IP patenting etc). Establishment and or operationalisation of Knowledge Production Fund and its open competitive access were recommended for sustaining higher knowledge investment and returns.
\end{abstract}

Keywords: Sustainable Knowledge; Investment; Returns; Production Function; Financial Method.

Citation: Ankamah E. F, Amoah J. Y, Sustainable Knowledge Investment and Returns in G hana, 2018; 3(1): 1-12.

Reeived: 9 Deecther 2017

Acepted 21 Deeenber 2017

\subsection{Introduction}

\subsection{Badkgaund}

The impact of tangible assets on standard of living is usually measured by per capita Gross D omestic Product (GDP). Wealthy economies (per GDP indicator) mostly organised production around tangible resources such as cheap fossil fuels. However, these nonrenewable natural resources result in pollution, scarcity and eventual decline in growth. These challenges concerning tangible resources preoccupy the thinking and search for intangible resources that will ensure endless and limitless growth.

The World Bank advocated for Knowledge Economy $(\mathrm{KE})$ as a means of attaining sustainable and continued economic growth. KEI indicators measures economic growth of one country relative to another in terms of moving, creating and using information concerning issues such as a country's ICT infrastructure, tertiary enrollment, computers per thousand persons, 1

(C2018 International Journal of Technology and Management Research ISBN 2026-6480 
amount of researchers in R\&D etc. These KEI indicators are not much endowed in Africa. This means that, in poor countries, availability of the aforementioned indicators is less than as it is in western quantity and quality.

Knowledge remains most vital force backing science and innovation, which in turn has forward linkage with technical progress, a key driver of sustained improvements in living standards (Frontier Economics, 2014). Knowledge, an intangible investment good, has predisposition to major financial expenditures and commensurable benefits (example, better health of humans and flora). In contrast to huge financial resources needed to be invested in knowledge production, the World Development Report (2008) confirmed low investment in knowledge production.

However, knowledge investment generates beneficial returns. The evidence of Frontier Economics (2014) found that public investment through research council investments, showed highest social returns from science-based and applied research than $R \& D$ conducted by civil and public service organisations such as public higher educational institutions. It is difficult to separate rates of return into public and private. Even as public capital and current investments are critical in the success of R\&D, effective fiscal incentives also remedy market failures in knowledge production.

Investment incentives are policy measures aim at attracting investment. They focused on economic performance - and were criticised for being inefficient - and that they also result in misallocation of public funds. However, it has been suggested that the investment incentives will result in more effective policy tool to remedy market failures such as public good in knowledge production, if linked to the United Nations' (UN) Sustainable D evelopment G oals SD Gs, (UNTAD World Investment Report 2014).

Knowledge investment rate of return is beneficial, because, knowledge is limitless intangible asset, growth enhancing and sustainable, thus, averting challenges of GDP and KEI which are also positively related. Quantitative positive rates of return confirm scientific benefits of knowledge such as averting air pollution and promotion of public health practices. 0 ther benefits are averting contamination of underground water bodies and eco-systems, reduction in greenhouse gas emissions as well as economics and health care credibility of rich flora.

In accordance with sustainable development these benefits improve quality of life of many generations; making knowledge investment a sustainable venture. Sustainable development; ensures gradual reversal in consumption of irreversible depletion of nonrenewable natural resource and minimises consumption of pollutants, which affect human health and the health of the climate. It means that a systematically derived Knowledge Investment Rate of Returns represents a measure of sustainable development.

Knowledge Investment Indicators gauge quality of higher education, improvement in scientific research and accelerate attainment or consolidation of achieved Sustainable Development Goals (SDG) in a poor country like Ghana. In fact, the study considers the investment rate of return as a financial measure that is efficient and fair to successive generations. Following this explanation, the object of this study is to calculate rates of return on knowledge investment in Ghana. 
Financial capital is the standard measure of financial health of broader knowledge capital including 1) physical capital directly involve in production, 2) ecological capital from nature, 3) social capital for community partnerships and 4) intellectual capital for academic criteria such as publications, collaborations, and research grants etc, produce knowledge on sustainable basis. Accounting segregates each knowledge capital and wealth into expendable net assets, plant debt, total revenues, total operating expenses, total non-operating expenses and change in total net assets etc. These are expressed in money terms, Thomashow (2014), and require investment to sustain it.

Sustainable Knowledge Investment is the sum of expenditures in research and development (R\&D), on total higher education (public and private) and on software, OECD (2005), which encompasses long-term, finance-driven strategies that integrate environmental, social and corporate governance (E SG) factors in investment arrangements. This demands a robust investment strategy, fashioned on large quantum of financial resources for a long-term investment.

\subsection{Empinical LiteratureandModds}

There are three intangible (including knowledge) categories of investments: - 1) Information Technology; 2) Innovative property - such as, scientific R\&D, exploration of minerals, costs of licensing and copyright, product design and development; 3) Economic competencies - including firm-specific human capital (training costs), market research and brand development, and investments in organisational capital and structure, (Corrado et al. 2005).

Guellec and Potterie (2003) suggested, three main ways in which the government can be involved in the production of knowledge through R\&D investments: a) Directly conducting the research themselves (through public research centres, or universities); b) Offering fiscal incentives (such as taxes and subsidies) to encourage research and development; c) Allocating grants to private companies to conduct research.

In Ghana, knowledge is mostly generated in the universities and the Council for Scientific and Industrial Research (CSIR). These knowledge producing institutions must be elevated from underinvestment to considerable meaningful investment expenditures. Currently, apart from G overnment of Ghana (GOG) subventions to research, alternative financing arrangements such as Public-Private Partnerships (PPP), remittances and diaspora bonds and combating Illicit Financial Flows (IFFs) are not directed at knowledge production.

According to Frontier Economics (2014), typically, the private returns from the production function method are much higher (net returns between $54 \%$ and $200 \%$ across different industries). Social rates of return in some studies vary from around $11 \%$ to $140 \%$. Most studies on public R\&D intangibles were modeled on only private sector, instead of the whole economy. This, explained the lower returns from public R\&D spending, including their impact on national health, education, security and public sector.

A significant amount of early evidence focused on the effect of spending on government research programmes in agriculture. Salter and Martin (2001), summaries 9 studies conducted between 1958 and 1993. These found social rates of return estimated at between $20 \%$ and $67 \%$, with typical values around $30-40 \%$. 
Empirically, broad economic models for computing investment rate of return to knowledge are the macroeconomic and microeconomic approaches (Frontier Economics 2014). The macroeconomic method measures returns directly by estimating a Cobb-D ouglas production function linking inputs (including measures of knowledge) to outputs. O ne of the three approaches to estimating the rate of return to knowledge capital based on the Cobb-D ouglas production function, incorporate an estimate of the size of knowledge capital stock, which Ankamah (2016), specified as; -

$\mathrm{Q}=\mathrm{B}_{0} \mathrm{~K}^{\mathrm{B} 1} \mathrm{~L}^{\mathrm{B} 2} \mathrm{R}^{\mathrm{B} 3}$

$\mathrm{Q}, \mathrm{K}, \mathrm{L}$ and $\mathrm{R}$ are measures of output, physical capital, labour and knowledge capital respectively. $\mathrm{B}_{0}$ is a constant. $\mathrm{B}_{1}$ is the coefficient/ elasticity of physical capital. $\mathrm{B}_{2}$ is the coefficient/ elasticity of output with respect to labour. This study is interested in $\mathrm{B}_{3}$ which estimates coefficient/ elasticity of output with respect to knowledge capital. $\mathrm{B}_{3}$ can be converted from measuring productivity to a rate of return alongside the ratio of the average size of Research and Development (R\&D) expenditure and revenue (i.e. R\&D intensity). Elasticity/ coefficient of knowledge capital was vital to calculate rate of return. Ankamah (2016), found a knowledge capital coefficient of 0.48\%, using CSIR-IIR Audited Financial Statements from 1997 to 2008.

The pathways of profit, lag and investments to the rates of return are much understood with the Financial Method for calculating rates of return. The financial method computes rates of return on investment (ROI) by dividing net profit (NP) by investment (I) and then multiplied by 100; -

$\mathrm{ROI}=\mathrm{NP} / \mathrm{I} * 100$.

The weight of net profit in investment rates of return is determined by profit function parameters. Campus Academic Resource Program with reference to Hass et al (2007), and Waner et al (2009), suggested that number of products or services transferred, per unit cost, price, variable cost and fixed cost are profit function parameters through the cost and revenue functions. Knowledge production through well established organisational structures and culture, maintenance of competencies and collaboration, Musiige, (2014), are facilitated by cost (investment expenditure).

In some cases, the value of investment must be estimated. The macroeconomic investment demand accelerator theory, otherwise called the accelerator principle or accelerator model is useful for the estimation. The model starts from the assumption of a fixed rate, relating output to the amount of capital normally require to produce it, that is fixed capital $\left(\mathrm{K}_{\mathrm{t}}\right)$ output $\left(\mathrm{Y}_{\mathrm{t}}\right)$ ratio, implying $\mathrm{K}_{\mathrm{t}}=\alpha \mathrm{Y}_{\mathrm{t}} \alpha$ is the distribution parameter. It assumes that firms always adjust their capital to their output so that the capital stock of the previous period $\left(\mathrm{K}_{\mathrm{t}-1}\right)$ must be in the ratio to the output of the previous period $\left(\mathrm{Y}_{\mathrm{t}-1}\right)$ that is $\mathrm{K}_{\mathrm{t}-1}=\alpha \mathrm{Y}_{\mathrm{t}-1}$. Net investment $\left(\mathrm{I}_{\mathrm{t}}\right)$ is the growth in capital stock between periods: -

$\mathrm{I}_{\mathrm{t}}=\mathrm{K}_{\mathrm{t}}-\mathrm{K}_{\mathrm{t}-1}=\alpha \mathrm{Y}_{\mathrm{t}}-\alpha \mathrm{Y}_{\mathrm{t}-1}=\alpha\left(\mathrm{Y}_{\mathrm{t}}-\mathrm{Y}_{\mathrm{t}-1}\right)$

$\mathrm{I}_{\mathrm{t}}=\alpha \Delta \mathrm{Y}$.

Thus net investment is proportional to the growth of output, rather than its level. Rising output brings about positive net investment and constant output brings about zero net investment and falling output brings about negative net investment. Thus, if depreciation is zero, the simplest accelerator model predicts that investment is proportional to the increase in output in the coming period. 
It is important to anticipate disadvantage in using different methodological approaches for computing either investment or rate of return. One characteristic of rates of return in many studies is fluctuation. For example, Stampone (2016), observed that average cap rate in first quarters of 2011 and 2016 were $8.53 \%$ and 6.84\% respectively and concluded that property prices have consistently increased over the last 5-7 years.

Explanations to rates of return fluctuation may not be extraordinary. First, long-term phenomenon of erratic R\&D results can contribute to fluctuation in rates of return. Second, measurement difficulties and methodological approaches in computing either investment or rate of return may also be sources of differences in empirical results overtime. However, the approaches are appropriate since the study concemed only the knowledge industry.

Another investment related issue that requires attention apart from net investment is the lag in knowledge investment that other studies such as Haskel et al. (2014), have equally considered. Lag includes; - 1) investment to returns lag, which is the time taken for an investment to generate returns and 2) returns to expiry of returns lag, which is the time taken for returns to persist or expire.

Lag between research investments and returns for different studies are heterogeneous. Private investments have shorter investment and returns lag. In private sector R\&D, mean lags are estimated to be around 1.2 and 4 years (Rapoport 1971, Wagner 1968). Public investments accrue future returns due to long lag. In public sector R\&D, existing evidence suggests that R\&D performed in the public sector takes much longer to generate return of 4.2 to 28 years.

The estimates will underestimate the time from investment to outcomes since they ignore lags between public investments and the production of academic publications so will understate the lags from investment to commercialisation. Even if lag times between investment and returns being realised are longer for public R\&D, as noted by Haskel et al. (2014), there are still many ways in which public funding (e.g. through academia) can yield more rapid benefits to business productivity and help drive more incremental innovation, such as advice and consultancy services and the training and employment of $\mathrm{PhD}$ students.

The thrust of this study that the introductory debate sorts to emphasize is to calculate rates of return indicators for knowledge assets which are intangible, limitless, growth enhancing and sustainable. This will resolve the weakness found in GDP per capita and KEI indicators.

\subsection{Methodology}

Primary and secondary data can centre on a case study design that entails detailed and intensive analysis of a single firm (Bryman 2012: 66). Case study approaches may focus on an individual, a group, or entire community and may utilise a number of data technologies such as: life histories, documents, oral histories, in-depth interviews and participant observations, (Berg, 2001: 225). This paper was based mainly on secondary data involving historical records that were derived from Council for Scientific and Industrial Research - Institute of Industrial Research (CSIR-IIR), Ghana.

The authenticity of the CSIR-IIR historical financial data was assured because it had been audited. The macroeconomic production function method and the financial method were tools employed to analyse the CSIR-IIR data. Frontier Economics (2014), detailed the methodological framework for using the production function to estimates returns from R\&D intangibles. 
The production function method is useful for time-series data at micro institute level as in this study. The method is flexible and the underlying framework is at least clearly grounded in economic theory and principles. It is econometrically robust means to estimate private or social return to knowledge investment.

The study limited the use of the production function methodology to only the first year of the study and concentrated on the financial method to analyse majority of the micro data concerning wider intangibles in unit of accounts (money). This is consistent with Thomashow (2014), that financial ratios reflect an assumption that wealth is best measured through its representation as money. Baafie Consult (2014). used the financial accounting method in a case study to compute returns on investment by analysing projected CSIR-IIR micro data.

Fortunately, values of capital assets and wealth have been fully disclosed in Council for Scientific and Industrial Research Institute of Industrial Research (CSIR-IIR) Ghana's Audited Financial Statements from 2009 to 2015. This is meritorious, because, it strongly signifies approval of the choice of the Financial Method, used extensively in calculating rates of return on investment.

Six years rates of return were calculated with the Financial Method. The data used for the analysis was a single case Audited Financial Statements of CSIR-IIR G hana: - which included the Income Surplus Account and the Balance Sheet from 2009 to 2015 prepared under standard accounting practice and convention. The Financial Statements contained variables with linkages to the rates of return via the Financial Method. These quantitative accounting variables were; - gross internally generated fund (IGF) i.e. revenue from output, net IGF or profit, fixed assets and stocks. The Financial Statements were supported by documents such as contract agreements, research project proposals, reports/ minutes and job requests.

Information concerning the direction of these variables was confirmed in the supporting accounting documents. $R \& D$, though positive was not much vibrant to increase wealth. This corroborated the financial statements, which showed that throughout the entire period (2009-2015) CSIR-IIR received only one donor-funded project in 2015. However, it was also indicated that high expertise gained from collaboration, improved efficiency and effectiveness in undertaking the few local and international consultancy services.

Collaboration was a mechanism that spread spillovers among industry researchers, thus influencing the data (CSIR-IIR financial data) used and so the resultant rates became social return for each year. It is also to be noted, that the values of the single (annual) rates of return were different (not repetitive) year - on - year. This conventionally provided basis for the calculation of mean rates of return on investment.

NP or (net IGF) was obtained from the income statement of CSIR. It was a function of profit parameters and collaboration. Greater NP, all other things being equal, will result in higher rate of return. Once net profit had been given and investment determined the former was divided by the later and then multiplied by 100 - refer to equation one (1). Three (3) mean rates were also derived from the six rate calculated with the financial approach.

CSIR-IIR is a knowledge producing institution, for which reason its assets are essentially intangible. The financial statements, (which confidentially cannot be shown entirely except for some important figures for this study), copiously captured values of 
all the fixed assets without any ambiguities. The values of capital assets were largely unstable and since capital is determined by investment the instability was attributed to flow of capital expenditure and depreciation.

However, the cash outlays that were termed GOG 'investments', turnout to be government subvention for workers compensation, i.e. monies for recurrent expenditure solely spent on salaries. They were not gradual releases of funds (investments) to increase wealth, assets and capital to sustain knowledge production and returns.

This means that the flow of funds i.e. the value of investments (I) that caused changes in assets were not disclosed in the accounting statements directly. Fortunately, information on gross income (G ross IG F) from 2009 to 2015 was available in the audited income statements. Hence, with understanding that R\&D output is not observable, investment was measured with gross income/ IGF, instead of output. The study assumed no depreciation because the fully depreciated machinery was routinely being used to deliver knowledge. Table 1 below shows gross IGF, expenditure, net IGF, stock, assets and investment.

Table 1

CSIR - IIR key financial variable from 2009 to 20015

\begin{tabular}{|c|c|c|c|c|c|c|c|}
\hline YEARS & 2009 & 2010 & 2011 & 2012 & 2013 & 2014 & 2015 \\
\hline \multicolumn{8}{|l|}{ IGF } \\
\hline \multicolumn{8}{|l|}{ GROSS } \\
\hline Ghф & 109,163 & 65,722 & 314,623 & 129,756 & 45,150 & 89,803 & 176,208 \\
\hline \multicolumn{8}{|l|}{ IGF EXP } \\
\hline Ghd & 123,398 & 68,970 & 154,934 & 52,869 & 50,658 & 32,681 & 74,773 \\
\hline \multicolumn{8}{|c|}{ - } \\
\hline \multicolumn{8}{|l|}{ IGF NET } \\
\hline Ghф & $-14,235$ & 3,248 & 159,689 & 76,887 & 5,508 & 57,122 & 101,435 \\
\hline $\begin{array}{l}\text { STO CK } \\
\text { Ghф }\end{array}$ & 24232 & 23326 & $\begin{array}{c}24232 \\
263,134\end{array}$ & $\begin{array}{r}23326 \\
158,279\end{array}$ & $\begin{array}{l}263,134 \\
299,128\end{array}$ & 296,672 & \\
\hline $\begin{array}{l}\text { FIXED } \\
\text { ASSETS } \\
\text { Ghф }\end{array}$ & 269,565 & $315,114^{2}$ & $\begin{array}{l}565 \\
22,505\end{array}$ & $\begin{array}{r}315,114 \\
24,532\end{array}$ & $\begin{array}{r}22,505 \\
30,602\end{array}$ & 27,240 & \\
\hline \multicolumn{8}{|l|}{ Investment } \\
\hline Ghф & & $-43,441$ & 248,901 & $-184,867$ & $-84,606$ & 44,653 & 86,405 \\
\hline
\end{tabular}


The verified gross income/ IGF was convenient to derive Investment (I) using the accelerator $\left(\mathrm{I}_{\mathrm{t}}=\alpha \Delta \mathrm{Y}\right)$. The accelerator model also fitted well with the financial data. Another, advantage of the accelerator principle was that it was able to capture impact of fixed assets, fully depreciated to nil value but physically in productive use. What was rather evident in place of depreciation was disinvestment relating to disposal of assets (decline in the value of assets) which emerged from observed drastic reduction in value of assets in table 1.

The production function formula for rates of return on investment (RO I) is given by:

ROI = R\&D Coefficient (elasticity) * average R\&D intensity * 100

$R \& D$ intensity has been defined as "the ratio of expenditures by a firm on research and development to the firm's sales/ revenue. The study divided the R\&D expenditure $(\mathrm{GH} \phi 123,398)$ by the gross IGF $(\mathrm{GH} \phi 109,163)$ in table 1 . Since the production function is restricted to the first one year of this study, the $R \& D$ intensity became the average ratio. To find the rate of return for only 2009, equation (4) was applied.

The coefficient of knowledge capital of $0.48 \%$ found in Ankamah (2016), was used because it was derived from the same institute and financial statements for the period 1997 to 2008. The closing balances of 2008 were carried forward to become opening balances for 2009. Thus, the coefficient can be used without any serious negative impact in 2009.

\subsection{Results and Discussions}

Results of calculated sustainable rates of return on knowledge investment followed the analysis of values of wealth, assets and capital of CSIR-IIR Ghana, (a knowledge institution). The mean social returns results were approximately 54, 36, -18 and 59\%. These results are lower than the recent higher returns reported for private and public sectors in developed nation. In confirmation, over 90 per cent of supporting Internal Management Committee (IMC) minutes analysed, pointed to existence of lower rate factors, including inadequate funding of $R \& D$, no IP policy (but on-going deliberation) and fewer patent right grants. Other qualitative rate reducing views were; erratic and very few projects from proposals.

However, from IMC presentations researchers were optimistic of the effect of skills (of scientists) gain through education and collaboration on rates of return. Indeed, this is a contributing factor in the positive mean rates shown in table 2 below. It appears the rates are akin to the higher range of social returns that Salter and Martin (2001) summarised for public R\&D investments between 1958 and 1993, of between 20\% and 67\%, with typical values around 30-40\%. Table 2 below shows the single and mean rates for the periods; -

Table 2

Single and mean Investment rates of return for the period

\begin{tabular}{llllllll}
\hline YEAR & 2009 & 2010 & 2011 & 2012 & 2013 & 2014 & 2015 \\
& & & & & & & \\
\hline R\&D intensity & 1.13 & & & & & \\
Average ROI - & $\left(1.13^{*} 0.48\right)$ & & & & & \\
production & $=0.5426 * 100$ & & & & & \\
\hline
\end{tabular}




\begin{tabular}{|c|c|c|c|c|c|c|c|}
\hline function & $=54.24 \%$ & & & & & & \\
\hline Single ROI - & & $7.48 \%$ & $64.16 \%$ & $-41.59 \%$ & $6.51 \%$ & $1.28 \%$ & $117.39 \%$ \\
\hline \multicolumn{8}{|l|}{ Financial } \\
\hline \multicolumn{8}{|l|}{ method } \\
\hline Mean ROI & & & $35.82 \%$ & & $-17.54 \%$ & & $59.34 \%$ \\
\hline \multicolumn{8}{|l|}{ Financial } \\
\hline \multicolumn{8}{|l|}{ method } \\
\hline 2010-2015 & & & & & & & \\
\hline
\end{tabular}

Authors' computation (2017)

Baafie Consult (2014) used the financial method with projected (not actual) investment to compute a single rate of return of $149 \%$ for 2015. This study measured single rate of return of 117\% for 2015 using the accelerator approach to investment measurement. In this study, the difference between the rate of return in the first year and the rates for the remaining years could be attributed to the different models (different measurement and methodological approaches), used for computing the rates of return.

Notwithstanding the measurement and methodological effects on empirical results other factors had remarkable impact on rates of return. It was not surprising that the evidence in CSIR financial statement and documents pointed to low public investment and low inflow of private projects. Government was committed to paying salaries but investment into research laboratories, equipment and other R\&D infrastructure was completely zero. In the work of Toole (1999), it was shown that a $1 \%$ increase in the stock of public basic research ultimately led to a $2.0 \%$ to $2.4 \%$ increase in the number of commercially available new chemical compounds.

Literature, has elaborated on the role of investment incentives in knowledge production. The incentives combined with investments (public and private) into knowledge assets, result in newer knowledge production techniques (innovation) in IP policy, employees training \& education and accessible medical fund (health) in line with SD Gs. This pro poor arrangement has potential to equitably, re-distribute the societal benefits (improvements in quality of humans and flora health) from knowledge production.

Another causal issue conceming the fluctuation was that, public auction documents supporting the financial statements indicated that there was massive disposal of physical assets in 2012. This disinvestment of 108.27\%, from 2011 to 2013 occurred simultaneously with the negative rate of return on investment, in line with the fact that knowledge investment positively correlates strongly with rates of return.

The mean rate of return at the end of 2015 represented a considerable increase over the previous negative mean rate. The study was curious to find what could have been the causal factor: (is it gradual movements in the value of knowledge investment or tax incentives or direct R\&D subsidies?). It was discovered that the surge in the 2015 rate was influenced by a form of investment under a housing policy, whereby money payments were made to researchers and other technical officers who owned residential houses. 
Perhaps, that was the only component of employee compensation (termed GOG 'investment') that can be classified as 'true' investment. Incentive payments called 'owner occupier allowance' to employees increased per the income statement. This study was of the view that this motivated more employees in knowledge production to own houses, which means residential asset (a category of macroeconomic assets) investment increased, reflecting in the last higher social returns.

Two cardinal dynamics, in table 2, relating to investment returns was observed. First, shorter investment and returns lag of 2 years (2010 and 2011) occurred, with increasing rate of retum. This is consistent with: - 1) the suggestion that public funding can yield more rapid benefits to businesses, Haskel et al. (2014) and - 2) also the private sector R\&D investment and return lag found to be 4 years (Rouvinen 2002).

Second, except for the negative rate in 2012, the positive returns recurred from 2013 to 2015. Knowledge does not depreciate as time progresses and so it continues to produce returns sometimes beyond the working life of assets and tapped talents. Additionally, research operations take time to produce result and its expenditures and revenue over the pendency of R\&D project is non-synchronised. With expectation of revenue inflow from already expended monies on knowledge production, the prediction was that lag between knowledge investment returns and expiry will prolong far beyond 2015, into the future, at least, up to the end of the remaining working life of newly trained researchers.

The empinically higher returns and the traditional GOG subvention were not enough to secure commensurate private investment. Knowledge production must be procured with substantial funds. To be sustainable, knowledge investment requires enormous capital account (Fund) and open competition process to access it. Haskel and Wallis, (2010), found that open competition led to compelling good outcome of research funds allocated to universities in UK. There were no records of operational Knowledge Fund and any competitive process of securing it.

\subsection{Conclusion}

GDP and KEI, which are indicators for utilisation of tangible assets and intangible wealth respectively, change positively over time and space. Both indicators were unable to minimise consumption of pollutants, which affect human health and the health of the climate. GDP could not reverse scarcity and growth reduction in nonrenewable natural resource. KEI indicators are also not much endowed in Africa.

This study computed investment rates of return, which indicate long term benefits, such as, good quality humans and flora health, from knowledge intangible capital assets and wealth. The production function and financial methods were used to analyse and calculate the rates of return from financial data concerning intangible knowledge production.

The 2009 rate of approximately 54\% was found with the production function. The rate for each of the remaining years of the study from 2010 to 2015 was ascertained with the financial analysis method. The mean rate for 2010 and 2011 was approximately 36\%. The next mean rate of approximately negative 18\% was the average of 2012 and 2013 rates respectively. The last mean rate of return for 2014 and 2015 was approximately 59\%. 
Public R\&D is more basic and risky than applied, and may require additional private investments to commercialised knowledge, so that returns are shared between public and private entities adequately. Collaboration was a means of diluting internal data with spillovers information from other firm/ institutes within the knowledge industry. Computations based on industry data resulted in social rates of return. There were fairly good number of technologies developed by CSIR-IIR. Spurring demand and consumption of knowledge, perhaps, by defining demand through IP patenting etc, may increase patronage in knowledge acquisition.

A new investment order that allows complementary role of public and private investments must replace the old blanket subvention investment regime. Government should set up or operationalise a Knowledge Fund, if any, and put in place open competition process to access it. Policymakers and managers of knowledge institution must facilitate establishment of schemes (private investment, IP right, incubation park etc.) to increase knowledge production and demand. Deprived research institutions must receive reimbursement of research expenditures. Managers of knowledge institutions and the Fund should consider the entire spectrum of growth enhancing intangibles assets (physical, social, financial, intellectual and ecosystem aesthetics). This study predicts efficient and fair sustainable development (for present and future generations) through knowledge investment.

\section{Reference}

1. Ankamah E., F., (2016), Empirical Investigation into Productivity in the Research Section of G hana, Jaumal of Ghama SienceAssoiation 17(1): 78-91.

2. Baafie Consult., (2014), Research Business Plan (2015 - 2019) for Council for Scientific and Industrial Research Institute of Industrial Research, Directorate

3. Berg, B., L., (2001), Qualitative Research Method for the Social Science, Long Beach S1111-c23 ALLYN AND BACON Boston $\bullet$ London $\bullet$ Toronto $\bullet$ Sydney

4. Corrado, C., et al. (2005), Measuring Capital and Technology: An Expanded Framework, in Corrado, C. Haltiwanger, J. Sichel, D., (eds.), Measuring Capital in the New Economy, Chicago: The University of Chicago Press

5. Council for Scientific and Industrial Research - Institute of Industrial Research., Balance sheet and Income Statement (2009)

6. Frontier Economics, (2014), Rates of Return to Investment in Science and Innovation, A Report Prepared for the Department for Business, Innovation and Skill (BIS)

7. Guellec, D. and Van Pottelsberghe De La Potterie, B., (2003), The impact of public R\&D expenditure on business R\&D , Economics of Innovationand NewTehndogy, 12(3), 225-43

8. Haskel, J. and Wallis, G., (2010), Public Support for Innovation, Intangible Investment and Productivity Growth in the UK Market Sector, IZA Disassion Paper, 4772, Institute for the Study of Labor (http:/ / ftp.iza.org/ dp4772.pdf) 
9. Haskel, J. Hughes, A. and Bascavusoglu-Moreau, E., (2014), The Economic Significance of the UK Science Base, Campaign for Science and Engineering (http:/ / www.sciencecampaign.org.uk/ UK ScienceBase.pdf)

10. Hass, J. \& Weir, M., (2007), University Calculus Boston: Pearson Addison - Wesley.

11. OECD , (2005), G lossary of statistical terms hittps/ / statscedorg gossary/ dłail.asp?.

12. Rapoport, J., (1971), "The anatomy of the product-innovation process: cost and time”, in Mansfield, E. (ed.), Research and innovation in the modern corporation, New York: Norton.

13. Rouvinen, P., (2002), The Existence of R\&D Spillovers: A Cost Function Estimation With Random Coefficients, Econarics of Innovation and NewTehndoges 11(6): 525-542.

14. Salter, A., J., and Martin, B., R., (2001), The economic benefits of publicly funded basic research: a critical review, Resurh Pdigy3(3): 509-532.

15. Stampone, J., (2016), Evaluating Investment Performance - A Look at the Past and Going Forward

16. Thomashow, M., (2014), The Nine Elements of a Sustainable Campus. The MIT Press, 2014.

17. Toole, A.A., (1999a), Public Regulation and Expected Profitability: The Determinants of Pharmaceutical Research and D evelopment Investment. StanfordInstitutefor EconmicPdigyRerarch WorkingPaper, Stanford University.

18. United Nations Conference on Trade and D evelopment (UNCTAD), World Investment Report (2014), Investing in the SD Gs: An Action Report.

19. Wagner, L., U., (1968), Problems in estimating research and development investment and stock. Procedings of the BusinessandEconomic Statistics Setion, American Statistical Association, 189-97.

20. Waner, S. and Costenoble, S., (2009), Math for Business Analysis (2nd ed.). O hio: Cengage Learning. 